\title{
From Downplaying to Giving Illiberal Responses: Jokowi's Populist Leadership Amidst COVID-19
}

\author{
Sakir $^{1, *}$, Fairuz Arta Abhipraya ${ }^{2}$, Dyah Mutiarin ${ }^{3}$ \\ ${ }^{1,2,3}$ Department of Government Affairs and Administration, Universitas Muhammadiyah Yogyakarta, Indonesia. \\ ${ }^{*}$ Corresponding author. Email: mas.sakir@fisipol.umy.ac.id
}

\begin{abstract}
Many countries have proven that they could rise from the COVID-19 pandemic. Yet, each country has different results in overcoming this pandemic due to some factors, specifically their leaders' role in responding to this pandemic. In Indonesia, Jokowi, as the official president has played central role in responding to the pandemic through his leadership. The rise of populist leaders in responding to the COVID-19 pandemic has become the main topic of holistic discussions among political scholars. This research aims to describe and analyse how Jokowi's populist leadership respond to the COVID-19 pandemic. This research uses the two-part populist leaders framework in making decisions amidst the COVID-19 pandemic by Brett Meyer to classify Jokowi's initial responses to the COVID-19 pandemic; and it is further developed through one of the populist types of framing, Cultural Populism. This research concludes that Jokowi's initial responses to the COVID-19 pandemic are a form of downplaying, and most of them are classified as cultural populism. However, worsening cases causes a significant shift in Jokowi's responses, making them harsher by means of the enforcement of illiberal policies. He takes advantage of the crisis in the name of emergency, which results in the decline of democracy and violations of the Human Rights and the Freedom of Speech.
\end{abstract}

Keywords: Populist Leader, Democracy Decline, COVID-19 Pandemic, Illiberal,

\section{INTRODUCTION}

Since discovered in early 2020, the COVID-19 pandemic has become a severe problem globally. Governments worldwide have struggled to prevent the spread of the virus and the worsening of economic development. Yet, many countries have proven that they can rise from this nonnatural disaster, though they could not perfectly restore their initial condition. However, some countries have done better. China is known as the initial source of the COVID-19 pandemic. However, their initial responses to this virus were significantly faster than other countries [1]. Next to China is Vietnam, a country with limited resources. Vietnam has proven that they could survive amidst the global pandemic [2]. In contrast, some countries are still suffering from this pandemic due to their late responses, such as Myanmar [3] and Indonesia[4].

As a country that is well-recognized as the world's fourth-largest population, Indonesia is very vulnerable to this pandemic because this deadly virus has a great potential to claim the lives of numerous people, and indirectly threaten the security of the neighboring countries [5]. That being said, Indonesia's approach to solving this problem is pivotal not only for citizens' survival but also for the success of the worldwide campaign against COVID-19. However, the fact has shown that by July 2021, Indonesia has become the world's top five countries with the highest daily cases of COVID-19 [6]. Studies suggest that Indonesia was rather late in taking initial actions in response to this pandemic [4], [7], [8].

In this case, the official president of Indonesia, Joko Widodo (Jokowi) plays a central role. His leadership is highly influential in determining the policy outcomes. In the world of politics, discussing the leadership style of the political elite cannot be separated from the term populist leadership style. Some political scholar argue that populist leaders take weak actions in handling a crisis [9], [10]. However, others argue differently [11]. Populism is a "thin ideology" with two components: the idea of a good people pitted against a corrupt elite; and the belief that politics should be an expression of the will of the people [12]. Since the COVID-19 pandemic spread in Indonesia, the studies on how populist leaders respond to the global pandemic have increasingly shown positive growth[13]-[15], including some studies related to populist local leaders' actions during the pandemic [16], [17], which explains how local leaders are utilizing crises to build their electability. On a national level, some political scholars also discuss Jokowi's populist leadership and his failure to handle the crisis [18], [19]. They argue that the increase of COVID-19 cases in Indonesia is the result of Jokowi's populist leadership. It has caused the executive's failure to develop a better disaster mitigation response, and the late response in controlling the virus. 


\section{FRAMEWORK AND RESEARCH METHOD}

\subsection{Framework}

The author will develop the idea of populism studies amidst a crisis due to the COVID-19 pandemic - in this case-Jokowi as the president of Indonesia. Initially, the authors planned to use the two-part populist leaders' framework in determining the decisions taken amidst the COVID-19 pandemic which is developed by Brett Meyer from 'Tony Blair Institute for Global Change' to classify Jokowi's decision in responding to the pandemic [20]. Brett Meyer argues that: 1.) leaders can downplay the crisis or take it seriously; and 2.) if they take it seriously, they can make either liberal or illiberal policies and enforcement responses.

Figure 1. The two-part populist leaders' decision tree for COVID-19 response framework

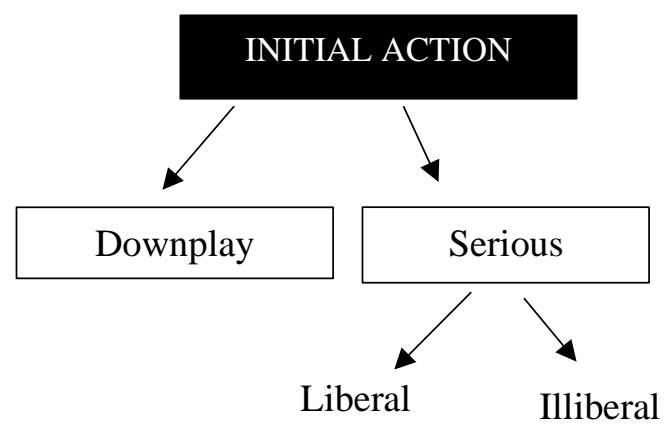

Source: [20]

Brett Meyer explains that there are two initial reactions given by populist leaders in facing the COVID-19 pandemic. Firstly, they prefer to downplay the threat of this epidemic. This can be seen in their policy reactions and how they behave in public. These are the three signs: 1.) The rejection of existing case reports 2.) The failure to implement the initial restrictions 3.) The downplaying of actors trying to advocate for a more robust approach against the pandemic. Secondly, leaders may prefer to take serious actions in controlling the COVID-19 pandemic. They could still take various action within the scope of their power during an emergency or within the predisposition of their requirement measures. If the size of this power expand or their requirements are one-sided against the groups of people with which the government has continuous strife, authors classify this reaction as an "illiberal" response.

There are three characteristics that must be possessed by a leader for him to be considered as having made a serious but illiberal policy in response to the emergency. Firstly, if the leader abuses power in the name of crisis with a few limitations in scope and length, like Hungary's power during an emergency bill [21]. Secondly, a moment of illiberal reaction is one with an unreasonable and merciless requirements, such as Rodrigo Duterte's "shoot to kill" policy for anybody refusing to comply with the social restriction[22]. Third, the illiberal reaction uses enforcement in a biased way, such as taking hostile actions toward independent media or other government adversaries. Liberal responses tend to utilize power in the name of crisis to put several proper enforcement measures in effect to solve a current issue, that are commonly free of political bias.

Subsequently, after the authors establishes the classification of Jokowi's actions in responding to the COVID-19 pandemic, this research will further identify whether Jokowi's leadership during the pandemic can be identified as populism according to Cas Mudde's Ideational Approach [12]. Mudde classifies populist leaders based on their leadership's frame in politics, namely whether their frame is deemed to have existential conflict among the 'true people' on the one hand and separation between insider (true people) and outsider groups (the others) on the other [23].

Populists constructed themselves as the manifestation of 'the people'; they claim themselves as the representative of the people. Commonly, populists have a terrible attitude in politics, often swear, display political inaccuracy and, usually, tend to dismiss the stiff dialect of technocratic politics [24]-[26]. They are skilled in rejecting political rightness, shunning information produced by experts and admiring the wisdom of regular people [27]. Additionally, populist policies attempt to connect their actions with the local culture of the people [28]. Populist leaders tend to silence scientific evidences and reject the presence of experts who are presenting the data that is different from their beliefs; therefore, the character of Antiscience is prominent among populists [29]. Anti-science populist leaders emerge as a result of the complex needs between political and economic stability [30].

In determining the type of populism, the actors who are considered as "the people" and "the others", and the "key themes", will be taken into consideration. Authors will identify Jokowi's leadership and Indonesia's central government responses based on these three general types of populism: Cultural, Socio-Economic, and Anti-Establishment [31].

Table 1. Three Types of Populists Frame in a 'Us vs. Them' Conflict

\begin{tabular}{|c|c|c|c|}
\hline & $\begin{array}{l}\text { Cultural } \\
\text { Populism }\end{array}$ & $\begin{array}{l}\text { Socio-economic } \\
\text { Populism }\end{array}$ & $\begin{array}{l}\text { Anti-Establishment } \\
\text { Populism }\end{array}$ \\
\hline The People & $\begin{array}{l}\text { 'Native' members } \\
\text { of the nation } \\
\text { state }\end{array}$ & $\begin{array}{l}\text { Hardworking, } \\
\text { honest members } \\
\text { of the working } \\
\text { class, which may } \\
\text { transcend national } \\
\text { boundaries }\end{array}$ & $\begin{array}{l}\text { Hardworking, } \\
\text { honest victims of } \\
\text { a state run by } \\
\text { special interests }\end{array}$ \\
\hline The Others & $\begin{array}{l}\text { Non-natives, } \\
\text { criminals, ethnic } \\
\text { and religious } \\
\text { minorities, } \\
\text { cosmopolitan } \\
\text { elites }\end{array}$ & $\begin{array}{l}\text { Big business, } \\
\text { capital owners, } \\
\text { foreign or } \\
\text { 'imperial' forces } \\
\text { that prop up an }\end{array}$ & $\begin{array}{l}\text { Political elites } \\
\text { who represent the } \\
\text { prior regime }\end{array}$ \\
\hline
\end{tabular}




\begin{tabular}{l|lll}
\hline & \multicolumn{3}{|c}{$\begin{array}{l}\text { international } \\
\text { capitalist system }\end{array}$} \\
\hline $\begin{array}{l}\text { Key } \\
\text { Themes }\end{array}$ & $\begin{array}{l}\text { Emphasis on } \\
\text { religious } \\
\text { traditionalism, law } \\
\text { and order, national } \\
\text { sovereignty, } \\
\text { migrants as } \\
\text { enemies }\end{array}$ & $\begin{array}{l}\text { Anti-capitalism, } \\
\text { working-class } \\
\text { solidarity, foreign } \\
\text { business interests } \\
\text { as enemies, often } \\
\text { joined }\end{array}$ & $\begin{array}{l}\text { Purging the state } \\
\text { from corruption, } \\
\text { strong leadership } \\
\text { to promote } \\
\text { reforms }\end{array}$ \\
\end{tabular}

Source: [31]

This research's objective is to explain and analyse the transition of Jokowi's response towards this pandemic, from downplaying to giving serious responses within the corridor of one of those three populism types. Based on the data obtained, this research argues that the prevalent type of populism utilised by Indonesia's central government in responding to the pandemic, which is observable in the government's policies, is Cultural Populism (see table 1). Therefore, in analysing and processing the findings, the authors will focus on cultural populism to identify the people (insider), the others (outsider) and the key themes.

\subsection{Research Method}

This research uses the qualitative research method by means of case study approach [32], [33]. A case study is an intensive research approach that describes one or two cases for a specific purpose in one bounded system through indepth and detailed data collection by involving various available sources of information [32], [34]. In the context of this research, Jokowi's populist leadership amidst the COVID-19 Pandemic shall constitute a case study.

This research explains a significant shift in Jokowi's responses in controlling this pandemic through the perspective of three populism types (see table 1); Jokowi is chosen as a case study because 1.) his leadership initially downplays this pandemic before shifting to giving serious responses through illiberal policies due to the worsening condition. However, this shift does not yield any positive impacts in terms of the number of cases. It even worsens the COVID-19 issues in Indonesia, which is currently one of the world's 5 top countries with the highest cases. His leadership plays an essential role in taking Indonesia out of this problem. 2.) Some existing works of literature explain Jokowi's populism amidst the COVID-19 pandemic. However, they are limited only to one-period case, and do not provide any explanations about the big shift in his leadership amidst the crisis; thus, this research will build on those findings.

In this research the data is collected using literature study aimed at explaining the research objectives. Literature study is a data collection technique carried out by researchers by collecting several written sources relating to the research problems and objectives. This method is used to manage various relevant information about the case study [35].

\section{FINDINGS AND DISCUSSION}

\subsection{Cultural populism response by downplaying the existing cases}

Since first discovered in early 2020, the COVID-19 pandemic in Mainland China has rapidly spread, and in less than a month, the pandemic has caused a series of events; from screenings in harbours to total lockdown affecting some cities. Rapidly growing cases was observed in several neighbouring countries around China, which then spread at an alarming rate to several countries globally. Several countries conducted social restrictions, travel bans, and even lockdown between January and February. However, Indonesia provided discounts for international tourists who want to visit Indonesia's tourist attractions instead [36].

This decision was based on Jokowi's claim that Indonesia has no coronavirus cases due to the virus being unable to survive in hot weather inside a tropical country like Indonesia. The claim was also supported by a quote from one of the American officials who are not even an expert in infectious disease studies. The claim was further strengthened by other statements such as one suggesting that Indonesians are immune to the virus and the self-praise toward the policies made by him [37]. His actions is construed as Anti-science, a trait possessed by a populist [18]. His responses have made the cases in Indonesia worsen.

In early march 2020, Indonesia's government officially announced the very first case [38]. Instead of conducting a restriction, Jokowi's prefers to provide socioeconomic assistances for the people. He issued a vague call to work, study, and pray at home but did not issue a stay-athome order. He rejected the suggestions regarding early prevention proposed by medical experts. Many parties also criticized him but to no avail [39]. For this reason, just in March 2020, many local leaders in Indonesia complained about his decision and asked Jokowi to issue a national restriction order immediately. Still, Jokowi ignored such request and prioritized the economic recovery. In the end, five regions decided to issue their own independent social restriction order [40]. Jokowi's act of downplaying is a sign of populism; anti-science tendency, the belief that one is a dominating party capable of representing 'the people', the failure of the perform initial restriction, and the rejection of existing case reports.

The sign of populism is also shown by Maa'ruf Amin, the vice president of Indonesia. Considering his background, he can be considered as one of the influential actors in the most prominent Islamic organization named Nahdatul Ulama. He argued that Indonesian people are immune to coronavirus because the prayers of Islamic scholars (Ulema) [41]. He displayed strong traditional religious values of the cultural populism. Another sign was shown by Terawan, Indonesia's Minister of Health. He 
rejected the experts' statements suggesting the existence of confirmed cases in Indonesia and the suggestion to perform mitigation measures to prevent worsening condition. He chose to recommend the Indonesian people to eat healthy food such as Indonesia's herbal medicine and relax in the middle of this situation [42]. There is a clear division between the role of the insider and the outsider in this case. Indonesia's central government is the insider, while the outsider is the experts and the people using a strong approach to advocate for better policies in controlling this pandemic.

\subsection{Serious responses through illiberal policies}

When the situation worsened, Indonesia's central government finally implemented more serious responses in solving the issue. The central government who were in denial struggled to produce effective policies to control the crisis. However, the latest trend of the political realm amidst the COVID-19 pandemic shows that most leaders in several countries are abusing their power in the name of the emergency condition. The most well-known case in Europe is Hungary. The Prime Minister of Hungary has issued an emergency bill to fight back coronavirus. However, this bill weakens the right of the parliament in conducting checks and balance; this bill has also silenced the journalists attempting to discover facts about the government [21]. Similar cases of actions which are harmful to democracy, namely illiberal policies, also occur in nine countries in Southeast Asia, including Indonesia [43].

Based on the index of democracy published by Freedom House, Indonesia is listed as partly democratic. The transition from 2020 to 2021 is the worst since the ranking goes from 61 to 59. This decline is caused by the abuse of power by Indonesia's central government and the violation of freedom of speech [44], [45]. The central government opposes people criticizing policies related to COVID-19 prevention, such as journalists, activists, experts, and academics [46]. Indonesia's central government tried to give serious responses to the cases. One of these responses was by conducting social restriction. It was not easy for the government to ensure that all people obey the rules to achieve social distancing. Despite that fact, utilizing repressive actions through state apparatus cannot be justified as a proper action. People were beaten at Labuan Bajo by the West Manggarai Police. Such case shows human rights violation in the name of emergency measures [47].

The political issues during the pandemic tend to be centered around how the government uses its power to solve this pandemic and maintain stability effectively. Indonesia's political freedom of speech repression is shown through the efforts taken to ensure the executive's good image. The police were asked to be more active and stern in protecting the president's image, as ordered by Telegram Number ST/1100/IV/HUK.7.1/2020 regulating the prohibition to insult the president and vice president via the internet as such act could be considered as a cybercrime that must be prevented. The perpetrator, according to Article 207 of the Criminal Code, will be subjected to a detainment for a maximum of 1 year and 6 months [48]. This law is aimed at creating a sense of security among the community using the internet. Under this law, the police must carry out cyber patrols to prevent fake news about the government's policies issued to curtail the COVID-19 pandemic.

However, this law has multiple interpretations. Acting as the insiders who consider the opposition groups as outsiders, the executives silence people who relentlessly advocate for stronger government policies in controlling the pandemic; in short, the outsiders can be considered as criminals. Ultimately, the public will be afraid to criticize the government for its inappropriate handling policies. We consider this action as a restriction of the freedom of speech of the people. There are some examples of the cases related to such statement. Ilyani Sudardjat questioned Indonesia's government claim suggesting that Indonesia had no corona cases. Her action was considered as an effort to spread fake news which may lead to public's panic [49]. Tempo Journalist experienced doxing and hacking [50]. Detik Journalist experienced terror, data leak, and threat due to his reports about the government's performance in controlling the pandemic. Anyone that harm the government's good image were attacked and prosecuted even when they were true. This action clearly harms press freedom and is in violation of Law Number 40 of 1999 [51].

The target for such action is not limited to journalists. Ravio Patra, a public policy scientist who criticized the government's transparency in maintaining COVID-19 information, allegedly "disappeared" after being arrested by the police. After that, his WhatsApp account was hacked and used to broadcast an incitement to carry out plundering [52]. Next, the twitter account of Pandu Riono, a scientist, was hacked after he questioned the COVID-19 vaccine developed by Airlangga University, Indonesian Army and Indonesian State Intelligence Agency [53]. Democratic consolidation through the cyberspace does not run well when the government uses state institutions to silence critical groups. These actions are justified as an effort to avoid fake news and create public stability amidst crisis. Such actions can serve as an evidence that 'Stealth Authoritarianism' is enforced amidst the COVID-19 pandemic. This term is associated with the effort of the government to hide their authoritarian leadership through a legal mechanism that seems lawful to be conducted. However, the fundamental objective is to create illiberal policies [54]. From several cases above, it can be concluded that 'the people' are native Indonesians that need to be protected by the president. Meanwhile, the outsider is a group of people that criticizes the government's policy. Furthermore, the key themes that the Indonesian government made for the public inside the populism framework are national sovereignty, law and order. 


\section{CONCLUSION}

Crisis, such as the pandemic, is a multidimensional disaster that is detrimental to various sectors. The leader of a country will do whatever it takes to solve this issue as soon as possible. However, the blame for the failure in controlling the pandemic cannot be placed solely on the virus itself, but also the leadership performed by the leader in getting the country out of the crisis caused by the pandemic. In this case, Jokowi and Indonesia's central government initially showed the characteristic of a populist, namely the act of downplaying the existence of this pandemic. However, when the case worsened, Jokowi showed a very significant shift in his responses. The social restrictions were carried out to reduce the mobilization and prevent the spread of the virus. Still, these serious actions did not heed the values of democracy and the policies were illiberal. The policies issued are still within the frame of cultural populism which harms democracy. From the democracy index reported in 2020 and 2021, it can be seen that Indonesia experiences the worst transitional decline of democratic index in the last five years.

\section{REFERENCES}

[1] N. S. AlTakarli, "China's Response to the COVID-19 Outbreak: A Model for Epidemic Preparedness and Management," Dubai Med. J., 2020, doi: 10.1159/000508448.

[2] B. T. T. Ha, L. N. Quang, T. Mirzoev, N. T. Tai, P. Q. Thai, and P. C. Dinh, "Combating the COVID-19 epidemic: Experiences from Vietnam," Int. J. Environ. Res. Public Health, vol. 17, no. 9, 2020, doi: 10.3390/ijerph17093125.

[3] R. Djalante et al., "COVID-19 and ASEAN responses: Comparative policy analysis," Prog. Disaster Sci., vol. 8, p. 100129, 2020, doi: 10.1016/j.pdisas.2020.100129.

[4] T. Chairil, “Indonesian Government's COVID-19 Measures, January-May 2020: Late Response and Public Health Securitization," J. Ilmu Sos. dan Ilmu Polit., vol. 24, no. 2, 2020, doi: https://doi.org/10.22146/jsp.55863.

[5] A. Hodge, "Coronavirus: Indonesia in need is the region's nightmare," theaustralian.com.au, 2020.

[6] Jakarta Globe, "Covid-19 Daily New Cases in Indonesia Is Now the 5th Highest in the World," jakartaglobe.id, Jakarta, 2020.

[7] D. Yulianti, I. F. MEUTIA, B. SUJADMIKO, and Wahyudi, "Indonesia' Crisis Response To Covid-19 Pandemic : From Various Level of Government and Network Actions To Policy," J. Public Adm. Financ. Law Indones., 2020.

[8] L. Agustino, “Analisis Kebijakan Penanganan Wabah Covid-19: Pengalaman Indonesia," J. Borneo Adm., 2020, doi: 10.24258/jba.v16i2.685.
[9] V. Bufacchi, "Is Coronavirus Bad for Populism?," 21st Century Global Dynamics, Apr. 27, 2020.

[10] E. Holland and H. Aron, "The Covid-19 crisis shows the failure of populist leadership in the face of real threats," LSE Phelan US Center, 2020.

[11] C. Mudde, "Will the coronavirus 'kill populism'? Don't count on it," The Guardian, Mar. 2020.

[12] C. Mudde, "Populism: An Ideational Approach," in The Oxford Handbook of Populism, 2017.

[13] Oskar Hutagaluh, Andi Rustam, Suwandi S. Sangadji, Ilfan Baharuddin, and Ardhariksa Zukhruf Kurniullah, "Responsive Leadership in Preventing Transmission of Covid-19 in the Indonesia-Malaysia Border Area," J. Adv. Res. Dyn. Control Syst., vol. 12, no. 02, pp. 3274-3279, 2020, doi: 10.5373/JARDCS/V12I2/S20201449.

[14] D. McDonnell, "Populist Leaders and Coterie Charisma," Polit. Stud., 2016, doi: 10.1111/14679248.12195.

[15] S. Fauziyah et al., "How should indonesia consider its neglected tropical diseases in the COVID-19 era? Hopes and challenges (review)," Biomed. Reports, vol. 14, no. 6, pp. 1-10, 2021, doi: 10.3892/br.2021.1429.

[16] F. A. Abhipraya, N. A. Vidayat, and W. A. Pamungkas, "Mencermati Populisme Pemimpin Lokal Sebagai Upaya Membangun Citra Ditengah Pandemi Covid-19," Gorontalo J. Gov. Polit. Stud., 2020, doi: 10.32662/gjgops.v3i2.1119.

[17] A. Muzwardi and S. D. Negara, "Batam's 2020 Mayoral Election: Populism, Economic Recovery and Covid-19," ISEAS Perspect., no. 9, pp. 1-13, 2021, [Online]. Available: https://thinkasia.org/handle/11540/13168.

[18] J. A. Lassa and M. Booth, "Are populist leaders a liability during COVID-19?," The Conversation, Jakarta, Apr. 08, 2020.

[19] M. Mietzner, "Populist Anti-Scientism, Religious Polarisation, and Institutionalised Corruption: How Indonesia's Democratic Decline Shaped Its COVID19 Response," J. Curr. Southeast Asian Aff., 2020, doi: $10.1177 / 1868103420935561$.

[20] B. Meyer, "Pandemic Populism: An Analysis of Populist Leaders' Responses to Covid-19," 2020. [Online]. Available: https://institute.global/policy/pandemic-populismanalysis-populist-leaders-responses-covid- 19.

[21] E. Szekeres, "Hungary 'No Longer a Democracy' After Coronavirus Law," balkaninsight.com, Bratislava, Mar. 31, 2020.

[22] L. Billing, "Duterte's Response to the Coronavirus: 'Shoot Them Dead',," foreignpolicy.com, Manila, 2020 . 
[23] J.-W. Müller, What Is Populism? University of Pennsylvania Press, 2016.

[24] M. Canovan, "Trust the people! populism and the two faces of democracy," Polit. Stud., 1999, doi: $10.1111 / 1467-9248.00184$.

[25] N. Neumann-Ernst, "Comparing populist communication across media channels: How political actors utilize populist messages and styles Thesis ( cumulative thesis )," Zurich Open Repos. Arch. Univ. Zurich ZORA, 2019.

[26] E. Block and R. Negrine, "The populist communication style: Toward a critical framework," Int. J. Commun., vol. 11, no. 1, pp. 178-197, 2017.

[27] R. R. Barr, "Populists, outsiders and antiestablishment politics," Party Polit., vol. 15, no. 1, pp. 29-48, 2009, doi: 10.1177/1354068808097890.

[28] R. Pankowski, The Populist Radical Right in Poland: The Patriots. Routledge, 2011.

[29] C. Hamilton, "Silencing the Scientists: the Rise of Right-wing Populism," ourworld.com, Canberra, 2011.

[30] S. E. Apitz, T. Backhaus, P. M. Chapman, W. Landis, and G. Suter, "Science, antiscience, and environmental decision making: A call to action," Integrated Environmental Assessment and Management. 2017, doi: 10.1002/ieam.1937.

[31] J. Kyle, "Populists in Power Around the World," 2018. [Online]. Available: http://institute.global/insight/ renewingcentre/populists-power-around-world.

[32] J. Creswell, "Qualitative, quantitative, and mixed methods approaches," in Research design, 2013.

[33] N. K. Denzin and Y. S. Lincoln, Introduction: The Discipline and Practice of Qualitative Research, Strategies. Sage Publications, Inc., 2008.

[34] J. Gerring, What is a case study and what is it good for? Cambridge: Cambridge University Press, 2004.

[35] E. Danial and N. Wasriah, Metode Penulisan Karya Ilmiah. Bandung: Laboratorium Pendidikan Kewarganegaraan, 2009.

[36] G. Intan, "Genjot Pariwisata di Tengah Wabah Virus Korona, Jokowi Janji Beri Diskon," voaindonesia.com, Jakarta, 2020.

[37] CNN Indonesia, "Jokowi Kutip Pejabat AS: Suhu Tinggi Perpendek Hidup Corona," cnnindonesia.com, Jakarta, 2020.

[38] M. I. Gorbiano, "BREAKING: Jokowi announces Indonesia's first two confirmed COVID-19 cases," The Jakarta Post, Jakarta, 2020.

[39] N. Smith, "Indonesian president admits he suppressed data on coronavirus spread," telegraph.uc.uk, 2020.

[40] H. A. Al Hikam, "Dilema Lockdown: Keselamatan
Masyarakat atau Perekonomian?," Detikfinance.com, Jakarta, 2020

[41] S. Maranda, "Indonesia Terhindar Virus Corona, Ma'ruf Amin: Berkah Doa Qunut," tempo.co, Jakarta, 2020.

[42] A. F. I. Sani, "Profesor Harvard Kaget Terawan Ngegas Soal Riset Virus Corona," nasiona.tempo.co, Jakarta, 2020.

[43] J. Gomez and R. Ramcharan, "Coronavirus and democracy in Southeast Asia," bangkokpost.com, Bangkok, Apr. 01, 2020.

[44] T. P. Power, "Jokowi's authoritarian turn and Indonesia's democratic decline," Bull. Indones. Econ. Stud., 2018, doi: 10.1080/00074918.2018.1549918.

[45] F. A. Abhipraya, M. E. T. Pahlevi, and A. A. Amrurrobi, "The Democratic Decline in Indonesia Under COVID-19 Pandemic," J. Wacana Polit., vol. 5, no. 2, 2020, doi: 10.24198/jwp.v5i1.28581.

[46] freedomhouse.org, "Freedom In The World 2021," 2021 .

[47] Floresa.co, "Lewat Video, Pemuda di Labuan Bajo Kisahkan Pemukulan oleh Polisi," www.floresa.co, Labuan Bajo, 2020.

[48] Ramadhan, "Di Tengah Pandemi COVID-19, Muncul Aturan Jerat Penghina Presiden," asumsi.co, Jakarta, Apr. 09, 2020.

[49] Kirana, "pengkerdilan ruang sipil di tengah pandemi," Jakarta, 2020. [Online]. Available: https://lokataru.id/wpcontent/uploads/2020/06/Untitled-3.pdf.

[50] D. Damarjati, "Situs Berita Tempo.co Diretas, Pemred Sebut Ada Upaya Pembungkaman," Detiknews.com, Jakarta, 2020.

[51] T. I. Oktavianti, "AJI urges police to investigate alleged intimidation, doxing of Detik journalist," The Jakarta Post, Jakarta, 2020.

[52] G. Ghaliya, “'I was kidnapped': Govt critic Ravio Patra files pretrial motion against police," The Jakarta Post, Jakarta, 2020.

[53] CNN Indonesia, "Akun Epidemiolog Pandu Riono Diretas, Dunia Akademis Terancam," cnnindonesia.com, Jakarta, 2020.

[54] O. O. Varol, "Stealth authoritarianism," Iowa Law Rev., 2015. 